\title{
Urantide decreases hepatic steatosis in rats with experimental atherosclerosis via the MAPK/Erk/JNK pathway
}

\author{
HAIPENG CUI $^{1 *}$, YINGXUE LIN $^{2 *}$, LIDE XIE $^{1}$ and JUAN ZHAO ${ }^{1}$ \\ ${ }^{1}$ Department of Pathophysiology, Chengde Medical University; ${ }^{2}$ Department of Medicine, \\ Affiliated Hospital of Chengde Medical University, Chengde, Hebei 067000, P.R. China
}

Received September 2, 2020; Accepted February 5, 2021

DOI: $10.3892 / \mathrm{mmr} .2021 .11923$

\begin{abstract}
Hepatic steatosis, an indicator of atherosclerosis (AS), is always accompanied by inflammatory responses and disturbances in lipid metabolism. The present study investigated the protective effect of urantide, a urotensin II (UII) receptor antagonist, on the liver of rats with AS with hepatic steatosis by regulating the MAPK pathway. AS was induced in rats via an intraperitoneal injection of vitamin $D_{3}$ and the administration of a high-fat diet. Urantide treatment was then administered to the rats. Pathology, liver index, lipid levels and liver function were measured to determine liver injury. The expression levels of UII and G protein-coupled receptor 14 (GPR14) were determined using immunohistochemistry, reverse transcription-quantitative PCR and western blotting. The expression levels of MAPK-related proteins in hepatocytes from each group were quantified using western blotting and immunofluorescence staining. Rats with AS had typical pathological changes associated with AS and hepatic steatosis, which were significantly improved by urantide treatment. Blood lipid levels, body weight, liver index and liver function were recovered in rats with $\mathrm{AS}$ after urantide treatment. Urantide downregulated the expression levels of UII and GPR14 in the livers of rats with AS; concurrently, the phosphorylation of Erk1/2 and JNK was significantly decreased. Moreover, no significant changes were observed in the phosphorylation of p38 MAPK in AS rat livers. In conclusion, urantide inhibits the activation of Erk1/2 and JNK by blocking the binding of UII and GPR14, thereby alleviating hepatic steatosis in rats with AS, ultimately restoring lipid metabolism in the liver and alleviating AS lesions.
\end{abstract}

Correspondence to: Dr Juan Zhao, Department of Pathophysiology, Chengde Medical University, 1 Anyuan Road, Shuangqiao, Chengde, Hebei 067000, P.R. China

E-mail: zhaojuan@cdmc.edu.cn

*Contributed equally

Key words: urantide, atherosclerosis, hepatic steatosis, urotensin II, $\mathrm{G}$ protein-coupled-receptor 14, Erk, JNK

\section{Introduction}

The liver is an important organ for lipid metabolism. In individuals with atherosclerosis (AS), lipid levels increase excessively, exceeding the liver metabolic capacity and damaging liver function and structure, thereby causing hepatic steatosis (1). According to multiple studies, hepatic steatosis is not only an indicator of AS but also an early regulatory factor that promotes the development of AS $(2,3)$. Indeed, both AS and hepatic steatosis, which is a lipid-storage disease, involve ongoing inflammatory responses and disturbances in lipid metabolism.

Urotensin II (UII), the most potent vasoconstrictor peptide, is involved in the pathophysiology of numerous disorders, including heart failure, essential hypertension, renal disease, diabetes and liver cirrhosis (4). By binding to its receptor G protein-coupled receptor 14 (GPR14), UII participates in the regulation of multiple signaling pathways, such as inflammation, cell proliferation and lipid metabolism $(5,6)$. Therefore, UII/GPR14 is regarded as a specific target for the treatment of $\mathrm{AS}$ and hepatic steatosis.

The MAPK pathway is an important signal transduction pathway occurring from the cell surface to the nucleus (7). Among the components of the MAPK pathway, Erk is involved in the regulation of cell proliferation and differentiation, JNK is the key molecule involved in stress-induced cell signal transduction and p38 MAPK (p38) mediates the occurrence of cell inflammation and apoptosis (8). Therefore, UII/GPR14 mediates the activation of MAPK signaling to induce vasoconstriction and vasodilation, as well as cell proliferation and migration $(4,9)$. However, the mechanism via which UII/GPR14 regulates MAPK activation in AS and its association with fatty liver remains unknown.

The peptide compound urantide is a type of UII receptor antagonist. Our previous studies have confirmed that urantide exerts protective effects on the thoracic aorta in rats with AS $(10,11)$. However, to the best of our knowledge, researchers have not yet determined whether urantide also exerts a protective effect on the livers of rats with AS. The current study used the AS rat model to study the protective effect of urantide on liver injury and to investigate the regulatory effect of UII/GPR14 on MAPK signaling in urantide-treated AS rats with hepatic steatosis. Therefore, the present results may provide experimental evidence for the clinical application of urantide. 


\section{Materials and methods}

Animal experiments. Urantide (peptide purity $>95 \%$ ) was synthesized by ChinaPeptides Co., Ltd., and has the following amino acid sequence: Glu-Thr-Pro-Asp-Cys-Phe-Trp-Lys-Ty r-Cys-Val.

All animals were maintained in accordance with the guidelines of the Certification and Accreditation of the People's Republic of China general requirements for quality and competence of laboratory animal institutions (GB/T 27416-2014) regarding animal care. A total of 45 male Wistar rats (age, 4 weeks; weight, 180-200 g) were purchased from Vital River Laboratory Animal Technology, Beijing, China [License no. SCXK (Jing)-2016-0011] and housed at a constant temperature of $22 \pm 2^{\circ} \mathrm{C}$ with a humidity of $40-60 \%$ and under a 12-h light/dark cycle, with free access to food and water. The rats were randomly divided into three groups, with 15 rats per group: The control group was fed basal feed daily, while the model group (AS) and urantide group were injected with $150 \mathrm{U} / \mathrm{kg}$ vitamin $\mathrm{D}_{3}$ (Animal Pharmaceutical Huasheng Technology, Harbin, China) for 3 continuous days to damage the arterial intima (12) and were fed a high-fat diet (Beijing Keao Xieli Feed Co., Ltd.), which was composed of $80.8 \%$ basal feed, $10 \%$ hog fat, $3.5 \%$ cholesterol, $0.5 \%$ sodium cholate, $5 \%$ refined sugar and $0.2 \%$ propylthiouracil. The AS rat model was established using previously described methods (13). Then, 4 weeks later, 5 rats from each group were randomly sacrificed using an intraperitoneal injection of $150 \mathrm{mg} / \mathrm{kg}$ pentobarbital sodium [Fortune (Tianjin) Chemical Reagent Co., Ltd.] to detect whether the AS rat model was successfully replicated. Following successful modeling, the urantide group was injected with $30 \mu \mathrm{g} / \mathrm{kg}$ urantide, while the control and model groups were injected with $30 \mu \mathrm{g} / \mathrm{kg}$ normal saline daily for 2 continuous weeks. In the present study, the dosage of urantide was based on two preliminary studies by Zhao et al $(10,11)$. After 6 weeks of treatment, all rats were fasted for 1 day, and the body weight of each rat was measured. Then, the rats were sacrificed using an intraperitoneal injection of $150 \mathrm{mg} / \mathrm{kg}$ pentobarbital sodium, and $5-8 \mathrm{ml}$ blood per rat was harvested from the aorta pectoralis. The liver weight of each rat was measured to calculate the liver index with the following formula: Liver index $=$ liver weight/body weight $\mathrm{x} 100 \%$. The tissues were collected and immediately frozen at $-196^{\circ} \mathrm{C}$.

Assessment of aortic atherosclerosis and hepatic histology. Sections of the aorta pectoralis and liver tissues were harvested, fixed with $10 \%$ formalin at $4^{\circ} \mathrm{C}$ overnight, dehydrated in $70-100 \%$ ethanol and finally embedded in paraffin. Then, paraffin sections were sliced into 5- $\mu \mathrm{m}$ thick sections and used for H\&E staining, immunohistochemistry and immunofluorescence. H\&E (Nanchang Yulu Experimental Equipment Co., Ltd.) was performed according to the manufacturer's instructions. Pathological changes in the aorta pectoralis and liver tissues were observed in ten microscopic fields at $\times 400$ magnification using a light microscope (Olympus Corporation).

The presence of positive granules in the atherosclerotic plaques and liver cells were visualized using immunohistochemical staining for UII and GPR14, and immu- nofluorescence staining for phosphorylated (p)-Erk1/2 and p-JNK. Immunohistochemistry was performed using the SP kit (cat. no. SP-9002; OriGene Technologies, Inc.) according to the manufacturer's instructions. Briefly, sections were blocked with $3 \% \mathrm{H}_{2} \mathrm{O}_{2}$ (cat. no. SP-9002; OriGene Technologies, Inc.) at $37^{\circ} \mathrm{C}$ for $30 \mathrm{~min}$ and then incubated with 1:100 dilutions of anti-UII antibody (cat. no. sc-52299; Santa Cruz Biotechnology, Inc.) and anti-GPR14 antibody (cat. no. sc-514460; Santa Cruz Biotechnology, Inc.) at $4^{\circ} \mathrm{C}$ overnight. Sections were then incubated with biotin-labeled goat anti-mouse IgG antibody (cat. no. SP-9002; OriGene Technologies, Inc.) at $1: 1,000$ at $37^{\circ} \mathrm{C}$ for $30 \mathrm{~min}$, incubated with $100 \mu \mathrm{l}$ horseradish enzyme labeled streptomycin (cat. no. SP-9002; OriGene Technologies, Inc.) at $37^{\circ} \mathrm{C}$ for $15 \mathrm{~min}$, incubated with $100 \mu \mathrm{l}$ DAB (cat. no. ZLI-9017; OriGene Technologies, Inc.) at $37^{\circ} \mathrm{C}$ for $5 \mathrm{~min}$, and mounted with neutral balsam. For immunofluorescence staining, the isolated paraffinized liver sections were dewaxed with xylene, and subjected to antigen retrieval with the EDTA antigen repair solution (cat. no. ZLI-9071; OriGene Technologies, Inc.) at $100^{\circ} \mathrm{C}$ for $2 \mathrm{~min}$. The sections were then rinsed with TBS- $0.1 \%$ Tween- 20 (TBST) at $37^{\circ} \mathrm{C}$ for 5 min, blocked with $10 \%$ goat serum (Beijing Solarbio Science \& Technology Co., Ltd.) in PBS- $0.1 \%$ Tween- 20 at $37^{\circ} \mathrm{C}$ for $1 \mathrm{~h}$ and incubated with 1:100 dilutions of anti-p-Erk1/2 (cat. no. 4370; Cell Signaling Technology, Inc.) and anti-p-JNK antibodies (cat. no. 9255; Cell Signaling Technology, Inc.) at $4^{\circ} \mathrm{C}$ overnight. Sections were then incubated with FITC-labeled anti-species-specific antibodies (cat. nos. A0562 and A0568; Beyotime Institute of Biotechnology) in the dark at $37^{\circ} \mathrm{C}$ for $1 \mathrm{~h}$, and stained with a DAPI solution in the dark at $37^{\circ} \mathrm{C}$ for $45 \mathrm{~min}$. Sections were then mounted with antifade mounting medium (Beyotime Institute of Biotechnology). Then, immunohistochemical and immunofluorescence staining were observed in ten microscopic fields at $\mathrm{x} 400$ magnification using a fluorescence microscope (Olympus Corporation). Digital quantification (Image-Pro Plus 6.0; Media Cybernetics, Inc.) was performed in a blinded manner.

Measurement of blood lipid levels, hepatic lipid levels and liver function. The plasma was centrifuged at $1,500 \mathrm{x} \mathrm{g}$ for $10 \mathrm{~min}$ at $4^{\circ} \mathrm{C}$, and the serum was stored at $-20^{\circ} \mathrm{C}$. An automatic biochemical analyzer was used to detect rat serum levels of calcium $\left(\mathrm{Ca}^{2+}\right)$, total cholesterol (TC), triglyceride (TG), high-density lipoprotein (HDL) and low-density lipoprotein (LDL), which were determined to assess the extent of AS in rats. The automatic biochemical analyzer was also used to measure alanine transaminase (ALT), aspartate aminotransferase (AST), $\gamma$ glutamyl transferase (GGT), lactate dehydrogenase (LDH-L), alkaline phosphatase (ALP), total bilirubin (TBIL), direct bilirubin (DBIL) and indirect bilirubin (IBIL), which were determined to assess liver function in rats. The measurements were made on the automatic biochemical analyzer (BS-480; Shenzhen Mindray Bio-Medical Electronics Co., Ltd.) at the 266 PLA Hospital (Hebei, China). Liver tissues $(1 \mathrm{~g})$ were homogenized and extracted with $10 \mathrm{ml}$ ice-cold dehydrated alcohol and then centrifuged at $1,500 \mathrm{xg}$ for $10 \mathrm{~min}$ at $4^{\circ} \mathrm{C}$. The hepatic levels of TC and TG were measured using Ultraviolet-Visible Spectrophotometry kits (cat. nos. BC1980 and BC0620; Beijing Solarbio Science \& Technology Co., Ltd.) according to the manufacturer's protocol. 
Table I. Primer sequences used to measure mRNA expression via reverse transcription-quantitative PCR.

\begin{tabular}{ll}
\hline Genes & \multicolumn{1}{c}{ Primer sequences $\left(5^{\prime} \rightarrow 3^{\prime}\right)$} \\
\hline UII & F:GGAGGAGCTGGAGAGGACTG \\
& R: GAGTCTCGGCACTGGGATCT \\
GPR14 & F: AATGGCTCTAGGGTCCTCCT \\
& R: AACAGCCTCTGTGATGGACA \\
$\beta$-actin & F: CAGGCATTGCTGACAGGATG \\
& R: TGCTGATCCACATCTGCTGG \\
\hline
\end{tabular}

UII, urotensin II; GPR14, G protein-coupled receptor 14; F, forward; $\mathrm{R}$, reverse.

Quantitation of gene expression. Total RNA was isolated from the rat livers using TRIzol ${ }^{\circledR}$ reagent (Tiangen Biotech Co., Ltd.) according to the manufacturer's protocol. The mRNA concentrations were measured using a Nano Drop spectrophotometer (Thermo Fisher Scientific, Inc.). The appropriate quantity of cDNA templates $(\sim 0.5 \mathrm{mg})$ was generated with a Fast Quant RT kit (Tiangen Biotech Co., Ltd.) at $42^{\circ} \mathrm{C}$ for $15 \mathrm{~min}$ and $95^{\circ} \mathrm{C}$ for $3 \mathrm{~min}$, according to the manufacturer's protocol. Reverse transcription-quantitative (RT-q)PCR was performed using a SuperReal PreMix Plus kit (Tiangen Biotech Co., Ltd.) at $95^{\circ} \mathrm{C}$ for $15 \mathrm{~min}$; followed by 40 cycles of $95^{\circ} \mathrm{C}$ for $10 \mathrm{sec}$ and $60^{\circ} \mathrm{C}$ for $32 \mathrm{sec}$, according to the manufacturer's protocol (14). All samples from 6 rats per group were measured in triplicate, and the mean value was used for the comparative analysis. Quantitative measurements were calculated using the $2^{-\Delta \Delta \mathrm{Cq}}$ method (15). $\beta$-actin served as the housekeeping gene for the comparison of the gene expression data. The primer sequences used for RT-qPCR analyses were synthesized by Takara Biotechnology Co., Ltd. and are listed in Table I.

Western blotting. The total protein was isolated from livers of 3 rats in each group using RIPA lysis buffer (Beijing Solarbio Science \& Technology Co., Ltd.), and the protein concentrations were evaluated using a BCA protein assay kit (Beijing Solarbio Science \& Technology Co., Ltd.). The samples were boiled at $100^{\circ} \mathrm{C}$ for $7 \mathrm{~min}$, and then $45 \mu \mathrm{g}$ protein/lane was separated using SDS-PAGE (10\% gel) and transferred to a PVDF membrane. The PVDF membrane was incubated with $5 \%$ fat-free milk powder dissolved in a TBS solution containing $0.1 \%$ Tween-20 (TBST) for $1 \mathrm{~h}$ at room temperature and then exposed to the following primary antibodies: Anti-UII (1:800), anti-GPR14 (1:800), anti-p-Erk1/2 (1:1,000), anti-Erk1/2 (1:1,000; cat. no. 4695; Cell Signaling Technology, Inc.), anti-p-p38 (1:1,000; cat. no. 4511; Cell Signaling Technology, Inc.), anti-p38 (1:1,000; cat. no. 8690; Cell Signaling Technology, Inc.), anti-JNK (1:1,000; cat. no. 9252; Cell Signaling Technology, Inc.), anti-p-JNK $(1: 1,000)$ and $\beta$-actin (1:1,000; cat. no. 4970; Cell Signaling Technology, Inc.) at $4^{\circ} \mathrm{C}$ overnight. The PVDF membrane was rinsed with TBST and incubated with horseradish peroxidase-labeled goat anti-rabbit or anti-mouse secondary antibodies (1:5,000; cat. nos. 074-1506 and 074-1806; KPL, Inc.) for $1 \mathrm{~h}$ at room temperature. The immunoreactive bands were visualized using the ECL western blotting substrate (Beijing Solarbio Science \& Technology Co., Ltd.). A grayscale analysis of the target protein bands was performed using Image-Pro Plus 6.0 software (Media Cybernetics, Inc.).

Statistical analysis. The experimental data were statistically analyzed using SPSS 20.0 software (IBM Corp.) and are presented as the mean \pm SEM of $\geq 3$ independent experiments. One-way ANOVA was used to compare the parameters among all groups followed by Tukey's post hoc test. $\mathrm{P}<0.05$ was considered to indicate a statistically significant difference. Statistical charts were produced using GraphPad Prism version 7.0 software (GraphPad Software, Inc.).

\section{Results}

Urantide prevents atherosclerotic development and hepatic steatosis in AS rats. The present study examined the pathological changes in the thoracic aorta and liver of rats in each group to determine whether the AS rat model was successfully established, and to assess the effects of vitamin $D_{3}$ and a high-fat diet on the livers of AS rats. As shown in Fig. 1, in the control group, the thoracic aortic membrane had a clear boundary between the vascular tunica externa, media and intima. The vascular endothelial cells of the thoracic aorta were arranged in an orderly manner, and the elastic fiber layer structure and vascular smooth muscle cells were intact in the tunica media. In the AS model group, the thoracic aorta exhibited marked calcification and inflammatory cell infiltration, vascular endothelial cells were significantly damaged, elastic fibers were broken and disintegrated, and vascular smooth muscle cells were atrophied in the tunica media. All AS rats presented typical AS pathological characteristics. Following treatment with urantide, the vascular endothelial cells were notably recovered, and calcification and inflammatory cell infiltration were significantly decreased. Moreover, the elastic fibers and vascular smooth muscle cells in the tunica media were restored to normal.

Correspondingly, in the control group, the morphology of hepatocytes and the structure of hepatic plates were normal, and hepatic sinusoids displayed a uniform and regular arrangement. In the AS model group, the hepatocytes were obviously swollen and deformed, the arrangement of hepatic sinusoids was disordered, and the hepatic plates did not have a clear boundary. Inflammatory cell infiltration and vacuole-like lipid droplets were observed in the cytoplasm, and some nuclei were shifted to one side of the cells, which indicated typical hepatic steatosis. In the urantide group, the morphology of hepatocytes was restored to normal, and the hepatic sinusoids were arranged uniformly and regularly (Fig. 1). Based on these results, it was suggested that vitamin $D_{3}$ combined with a high-fat diet successfully induced AS and hepatic steatosis in rats, and urantide ameliorated the AS-related pathological changes and hepatic steatosis.

Urantide restores the $\mathrm{Ca}^{2+}$, blood and hepatic lipid levels, body weight and liver index in rats with $A S$. Vitamin $\mathrm{D}_{3}$ combined with a high-fat diet induces AS and hepatic steatosis, resulting in lipid deposition in the blood and liver (12). The current study 

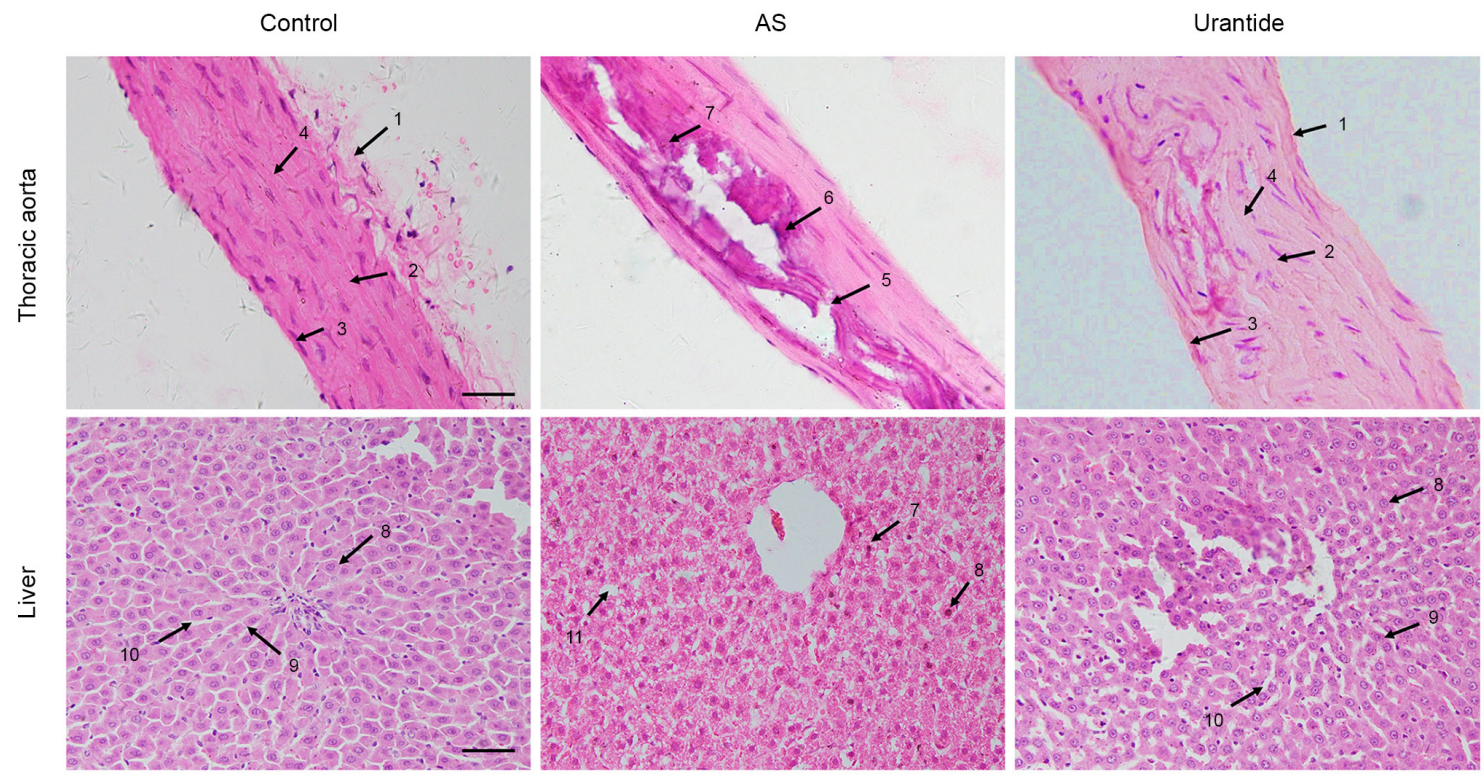

Figure 1. Morphological characteristics of the thoracic aorta and liver tissues from rats in each group. Arrows 1, vascular tunica externa; 2, vascular tunica media; 3, vascular tunica intima; 4, elastic fibers; 5, broken elastic fibers in the vascular tunica media associated with atherosclerosis; 6 , calcification associated with AS; 7, inflammatory cell infiltration; 8 , hepatocytes; 9 , hepatic plate; 10 , hepatic sinusoid; 11 , steatosis in hepatocytes. H\&E staining; scale bar, $20 \mu$ m. AS, atherosclerosis.

A

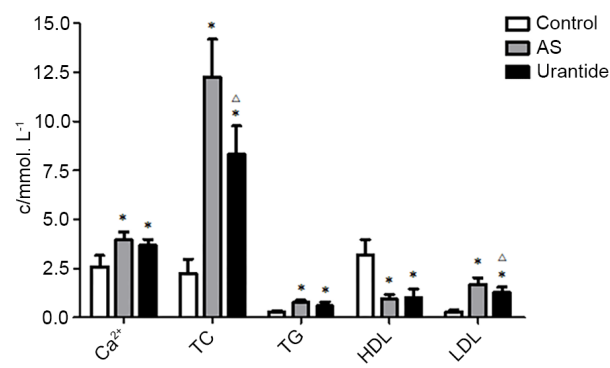

C

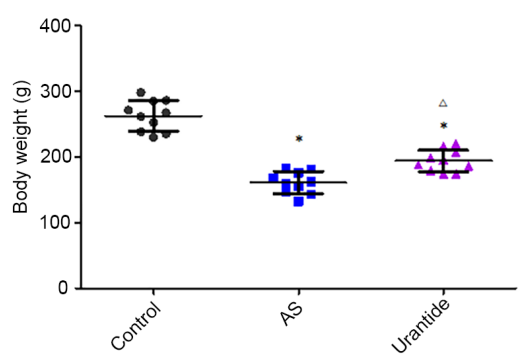

B
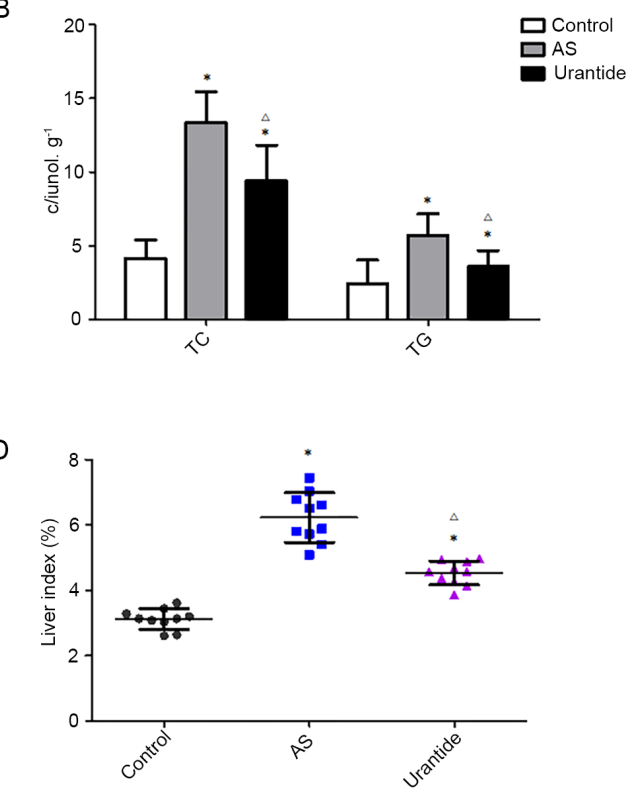

Figure 2. $\mathrm{Ca}^{2+}$ levels, blood and hepatic lipid levels, body weight and liver index in rats from each group. (A) Ca ${ }^{2+}$ and blood lipid levels in rat serum. (B) Hepatic lipid levels in rat liver tissues. (C) Body weight of each rat was measured after 6 weeks of treatment. (D) Changes in the liver index in each group. The data are presented as the mean \pm SEM, $\mathrm{n}=10$ animals per group. ${ }^{*} \mathrm{P}<0.05$ vs. control group; ${ }^{\Delta} \mathrm{P}<0.05$ vs. AS group. Ca ${ }^{2+}$, calcium; TC, total cholesterol; TG, triglyceride; HDL, high-density lipoprotein; LDL, low-density lipoprotein; AS, atherosclerosis.

measured the serum $\mathrm{Ca}^{2+}$ and blood lipid levels to investigate the antihyperlipidemic effects of urantide. Compared with the levels in the control group, the serum levels of $\mathrm{Ca}^{2+}, \mathrm{TC}, \mathrm{TG}$ and LDL in the AS model group were significantly increased, and the HDL levels were decreased. Furthermore, the TC and LDL levels in the urantide group were significantly decreased, and no changes in the levels of $\mathrm{Ca}^{2+}$, TG and HDL were observed, compared with the model group. Thus, urantide improved TC and LDL levels in rats with AS (Fig. 2A). The hepatic lipid levels and the liver index were also measured to examine the effects of urantide on hepatic steatosis. Compared with the levels in the control group, the hepatic levels of TC and TG in the AS model group were significantly increased, while the levels in the urantide group were significantly decreased (Fig. 2B).

The body weight was significantly decreased, and the liver index was significantly increased in the AS model group compared with the control group. Following treatment with urantide, the body weight and liver index in the urantide groups were both significantly recovered compared with the 
Table II. Serum ALT, AST, GGT, LDH-L and ALP levels in rats from each group.

\begin{tabular}{lcrr}
\hline Parameter & Control & \multicolumn{1}{c}{ AS } & Urantide \\
\hline ALT, U/1 & $46.18 \pm 8.66$ & $81.82 \pm 19.34^{\mathrm{a}}$ & $60.62 \pm 16.04^{\mathrm{b}}$ \\
AST, U/1 & $88.03 \pm 14.79$ & $148.20 \pm 50.41^{\mathrm{a}}$ & $112.00 \pm 52.07^{\mathrm{b}}$ \\
GGT, U/1 & $0.47 \pm 0.16$ & $3.07 \pm 0.54^{\mathrm{a}}$ & $2.30 \pm 0.67^{\mathrm{a}, \mathrm{b}}$ \\
LDH-L, U/1 & $177.80 \pm 52.20$ & $393.70 \pm 119.00^{\mathrm{a}}$ & $172.80 \pm 29.33^{\mathrm{b}}$ \\
ALP, U/1 & $151.10 \pm 35.51$ & $276.50 \pm 26.09^{\mathrm{a}}$ & $209.10 \pm 45.43^{\mathrm{a}}$ \\
\hline
\end{tabular}

Serum levels of the factors were detected using an automatic biochemical analyzer. The data are presented as the mean \pm SEM, $\mathrm{n}=10$ animals per group. ${ }^{\mathrm{a}} \mathrm{P}<0.05$ vs. control group; ${ }^{\mathrm{b}} \mathrm{P}<0.05$ vs. AS group. ALT, alanine transaminase; AST, aspartate aminotransferase; GGT, $\gamma$ glutamyl transferase; LDH-L, lactate dehydrogenase; ALP, alkaline phosphatase.

Table III. Serum TBIL, DBIL and IBIL levels in rats from each group.

\begin{tabular}{lccr}
\hline Parameter & Control & AS & Urantide \\
\hline TBIL,$\mu \mathrm{mol} / 1$ & $0.60 \pm 0.26$ & $1.39 \pm 0.44^{\mathrm{a}}$ & $0.76 \pm 0.49^{\mathrm{b}}$ \\
DBIL,$\mu \mathrm{mol} / 1$ & $0.25 \pm 0.08$ & $0.37 \pm 0.15$ & $0.47 \pm 0.16$ \\
IBIL,$\mu \mathrm{mol} / 1$ & $0.18 \pm 0.06$ & $0.63 \pm 0.16^{\mathrm{a}}$ & $0.23 \pm 0.12^{\mathrm{b}}$ \\
\hline
\end{tabular}

Serum levels of the factors were detected using an automatic biochemical analyzer. The data are presented as the mean \pm SEM, $\mathrm{n}=10 \mathrm{per}$ group ${ }^{\mathrm{a}} \mathrm{P}<0.05$ vs. control group; ${ }^{\mathrm{P}}<0.05$ vs. AS group. TBIL, total bilirubin; DBIL, direct bilirubin; IBIL, indirect bilirubin.

model group (Fig. 2C and D). Therefore, urantide effectively alleviated hepatic steatosis in rats with AS

Urantide improves the liver function of rats with AS. Liver function was assessed by measuring biochemical indexes to investigate the degree of liver injury in rats with AS, according to a method described by Lu et al (16). Compared with the levels in the control group, the serum levels of ALT, AST, GGT, LDH-L, ALP, TBIL and IBIL in the AS model group were significantly increased (Tables II and III). Following treatment with urantide, the ALT, AST, GGT, LDH-L and IBIL levels in the urantide group were significantly decreased compared with the levels in the AS model group. Furthermore, the levels of DBIL showed no significant changes in the rats from any group (Tables II and III). In conclusion, rats with AS exhibited liver dysfunction, and urantide improved liver function, particularly hepatic synthesis, storage and metabolic functions, in rats with AS.

Expression levels of UII- and GPR14-positive particles are significantly upregulated in the thoracic aortas and livers of rats with $A S$. Immunohistochemical staining identified significantly higher expression levels of UII- and GPR14-positive particles in the thoracic aortas of rats in the AS model group compared with in the control group, and those indexes were significantly lower in the urantide group compared with the model group (Fig. 3A and B). Consistent with these findings, the expression levels of UII- and GPR14-positive particles in the livers of rats in the model group were also significantly increased compared with the control group, and urantide significantly decreased those indexes in the livers of rats with AS. Based on these results, the UII/GPR14 system may serve an important role in hepatic steatosis in rats with AS, and urantide-mediated inhibition of the UII/GPR14 system effectively improves hepatic steatosis.

Urantide inhibits the UII/GPR14/MAPK pathway in the livers of rats with $A S$. The present study measured the mRNA and protein expression levels of UII and GPR14, as well as intermediates in the MAPK pathway, in the liver tissues of the rats in order to examine the molecular mechanism via which UII/GPR14 affects hepatic steatosis in AS rats. Significantly higher mRNA and protein expression levels of UII and GPR14 were detected in the liver tissues of rats in the model group compared with in the control group, and significantly lower mRNA and protein expression levels of UII and GPR14 were observed in the urantide group compared with in the model group (Fig. 4A and B). Consistent with these findings, compared with the control group, expression levels of the p-Erk1/2 and p-JNK proteins were significantly increased in the liver tissues of rats in the model group, and expression levels of the p-Erk1/2 and p-JNK proteins were significantly decreased in the urantide group compared with the model group (Fig. 4C). Moreover, the expression levels of the Erk1/2, p-p38, p38 and JNK proteins were not markedly changed in the liver tissues of rats in the various groups (Fig. 4C). Thus, hepatic steatosis in rats with AS was closely associated with the Erk1/2 and JNK pathways, and urantide significantly inhibited the activity of the Erk1/2 and JNK pathways. Therefore, urantide may effectively improve hepatic steatosis in rats with AS by regulating the Erk1/2 and JNK pathways. 
A
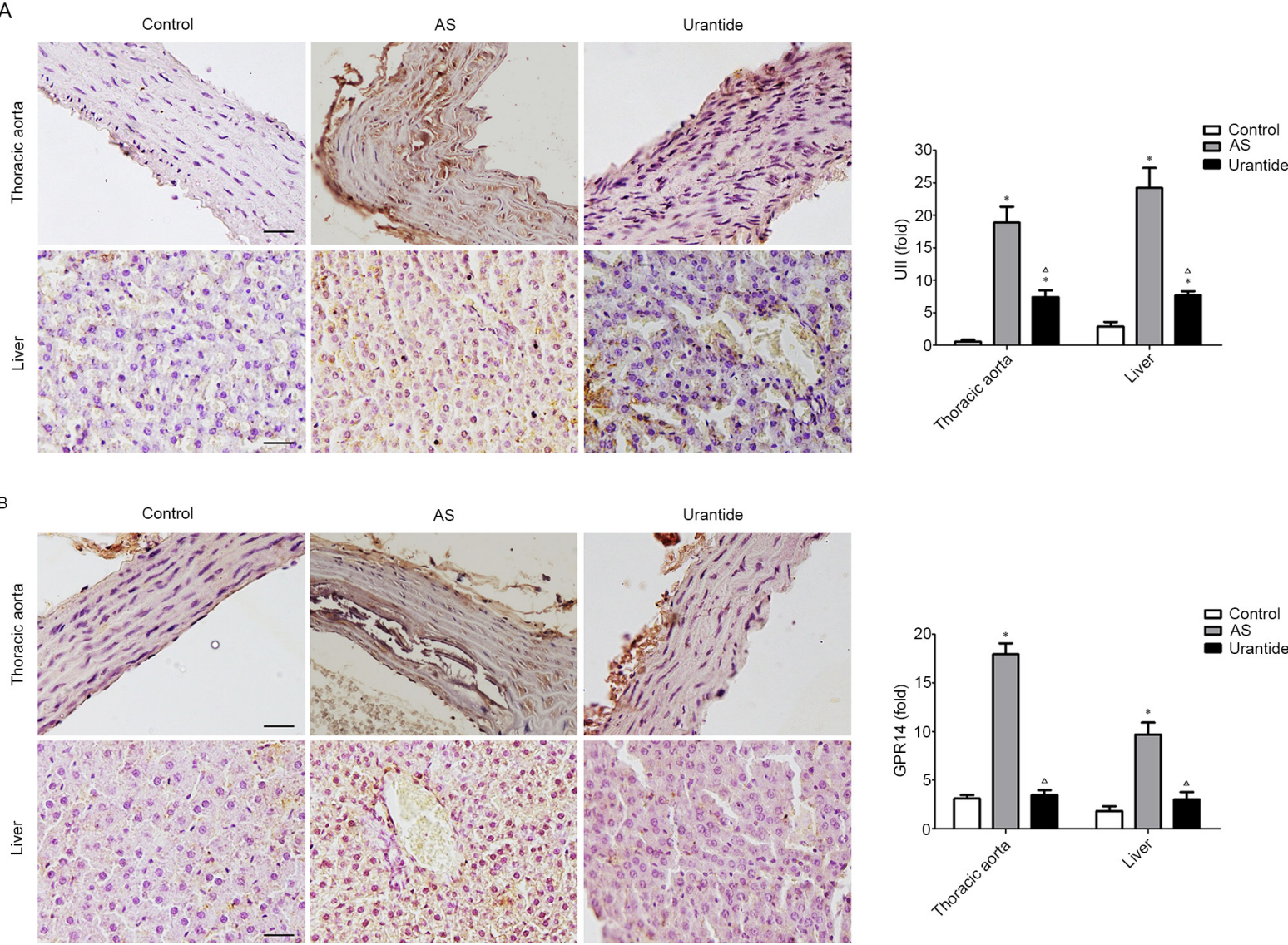

Figure 3. Expression levels of UII- and GPR14-positive particles in the thoracic aortas and livers of rats, as determined using immunohistochemical staining Expression levels of (A) UII and (B) GPR14 in the thoracic aortas and livers of rats. Scale bar, $20 \mu \mathrm{m}$. The data are presented as the mean \pm SEM, $\mathrm{n}=3$ animals per group. " $\mathrm{P}<0.05$ vs. control group; ${ }^{\wedge} \mathrm{P}<0.05$ vs. AS group. AS, atherosclerosis; UII, urotensin II; GPR 14, G protein-coupled-receptor 14.

Localization of $p$-Erk1/2 and p-JNK protein expression in the livers of rats. The localization of UII and GPR14 was further analyzed to determine whether the UII/GPR14 system directly or indirectly affects the Erk1/2 and JNK pathways. These proteins were mainly expressed in perivascular and necrotic hepatocytes, as detected using immunohistochemistry. Consistent with these findings, p-Erk1/2 and p-JNK displayed similar localization patterns, as detected using immunofluorescence staining. Moreover, urantide significantly decreased the expression levels of p-Erk1/2 and p-JNK-positive particles in the livers of rats with AS (Fig. 5A and B). Based on these results, it was suggested that the MAPK/Erk/JNK pathway was substantially activated in the livers of rats with AS. Moreover, the expression levels of p-Erk1/2 and p-JNK are gradually restored in rats with AS treated with urantide.

\section{Discussion}

AS is a process marked by chronic inflammation of the arterial wall due to infiltration of lipids, macrophages and other inflammatory mediators $(1,10)$. An increasing number of adverse cardiovascular disease events have been shown to be associated with non-alcoholic fatty liver disease, including dyslipidemia, inflammation and liver dysfunction (17). Non-alcoholic fatty liver disease is either an independent primary disease or a pathological manifestation of other systemic diseases, such as AS, in which non-alcoholic fatty liver synergistically promotes
AS occurrence and development $(18,19)$. An AS rat model was established in the current study, and the incidence of hepatic steatosis in rats was increased by feeding the rats a high-fat diet to enhance blood and hepatic lipid levels. Concurrently, the effect of urantide-mediated alleviation of AS was associated with a decrease in hepatic steatosis. Then, liver index and function were tested to investigate the degree of liver injury in rats with AS. The results demonstrated that rats with AS had liver dysfunction, according to Lu et al (16), and urantide restored the liver function in rats with AS and decreased liver injury, resulting in protective effects on the livers of rats with AS. Furthermore, the expression levels of UII and GPR14 in the livers of AS rats were significantly increased, which was consistent with the results observed in the thoracic aorta. Thus, it was suggested that the UII/GPR14 system may serve an important role in hepatic steatosis in rats with AS, and the protective mechanism of urantide may involve inhibiting the expression of UII and its receptor GPR14 in the livers of rats with AS.

The somatostatin-like cyclic peptide UII was first isolated from the urophysis of bony fish (20), and the UII/UT system is involved in the pathogenic mechanism that promotes AS occurrence and development $(10,21)$. Furthermore, the UII/UT system promotes inflammation and accelerates foam cell formation $(22,23)$. However, to the best of our knowledge, the role of the UII/UT system in AS-associated liver injury has not been previously reported. According to Sun et al (24), 


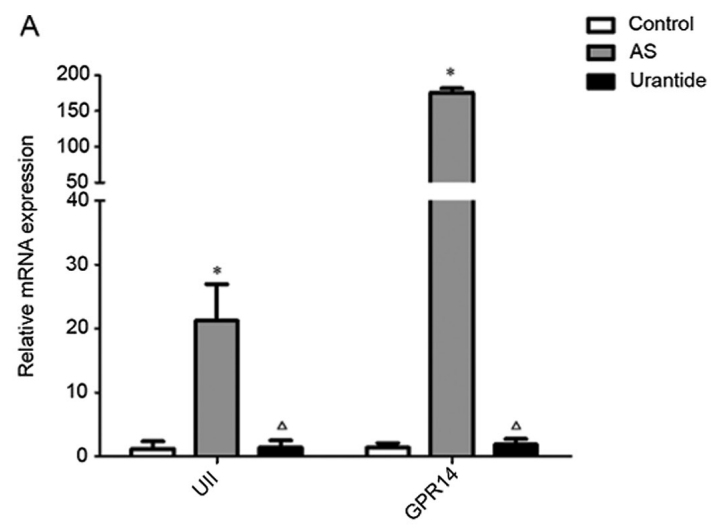

B

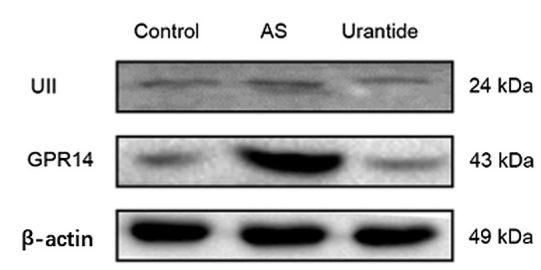

C

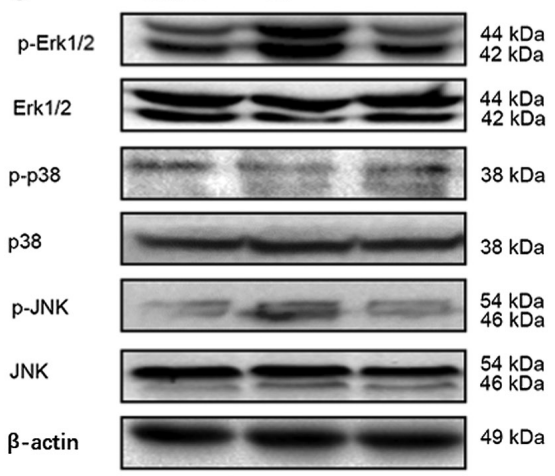

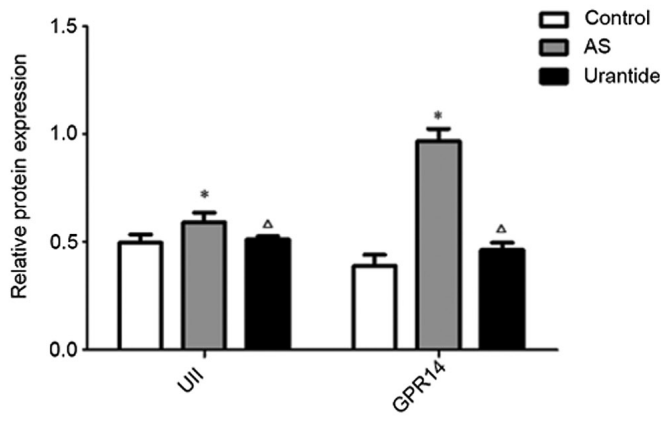

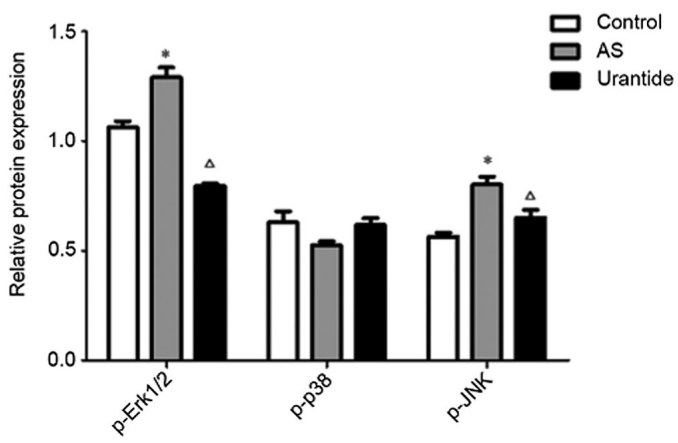

Figure 4. Expression levels of UII, GPR14 and MAPK in the liver tissues of rats in different groups. (A) UII and GPR14 mRNA expression levels in the liver tissues were determined using reverse transcription-quantitative PCR. (B) UII and GPR14 protein expression levels in liver tissues were determined using western blotting. (C) Expression levels of proteins in the MAPK signaling pathway in liver tissues were determined using western blotting. The data are presented as the mean \pm SEM, $n=3-6$ animals per group. ${ }^{*} \mathrm{P}<0.05$ vs. control group; ${ }^{\Delta} \mathrm{P}<0.05$ vs. AS group. AS, atherosclerosis; UII, urotensin II; GPR14, G protein-coupled-receptor 14 ; p-, phosphorylated.

UII/GPR14 signaling is involved in CCl4-induced liver injury by inducing inflammation and oxidative stress. In addition, the UII/UT system induces acute liver failure by triggering an inflammatory cascade $(25,26)$.

To further examine the regulatory molecular mechanism of UII/GPR14 in hepatic steatosis and the pathogenesis of AS, the phosphorylation of MAPK signaling molecules was examined in the livers of rats from various groups. The binding of UII to its receptor GPR14 has been shown to increase the phosphorylation of Erk and promote the contraction and proliferation of vascular smooth muscle cells, and thus participate in the occurrence and development of AS $(3,9,27)$. After phosphorylation, Erk is transferred from the cytoplasm to the nucleus where it mediates the activation of transcription factors, such as ETS domain-containing protein, activating transcription factor, amino acid permease 1, c-Fos and c-Jun, and participates in the development of hepatic steatosis (28). The phosphorylation of JNK may also serve a role in AS inflammatory reactions (29). In addition, p38 MAPK is involved in inflammatory signaling and is activated in response to oxidative stress, cytokines and growth factors, all of which are abundantly present in AS and aortic valve sclerotic lesions (30). As demonstrated in the current study, UII and GPR14 expression levels were significantly increased in the livers of rats with AS, and the corresponding levels of phosphorylated Erk1/2 and JNK were significantly increased. Interestingly, the data from the present study revealed that p38 phosphorylation was not significantly increased in the livers of rats with AS. Thus, p38 may not serve an important role in hepatic steatosis, and a similar result has been reported by Kardakaris et al (31). Therefore, it was 
A
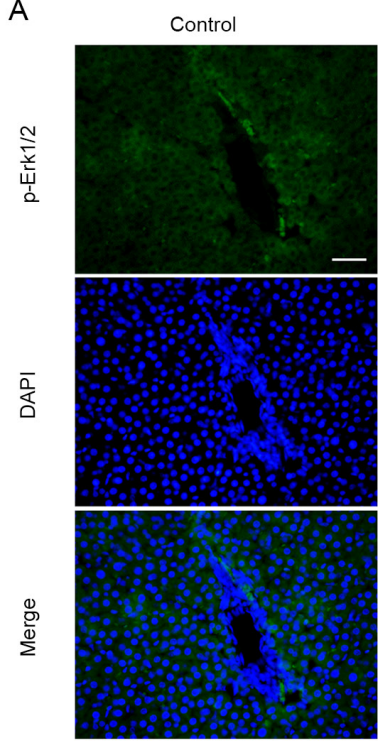

B
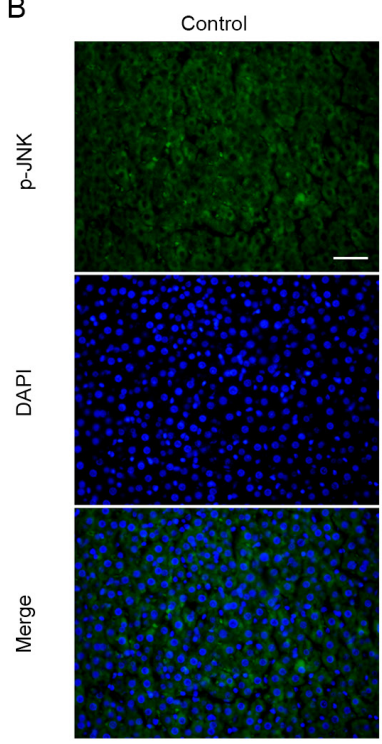

AS
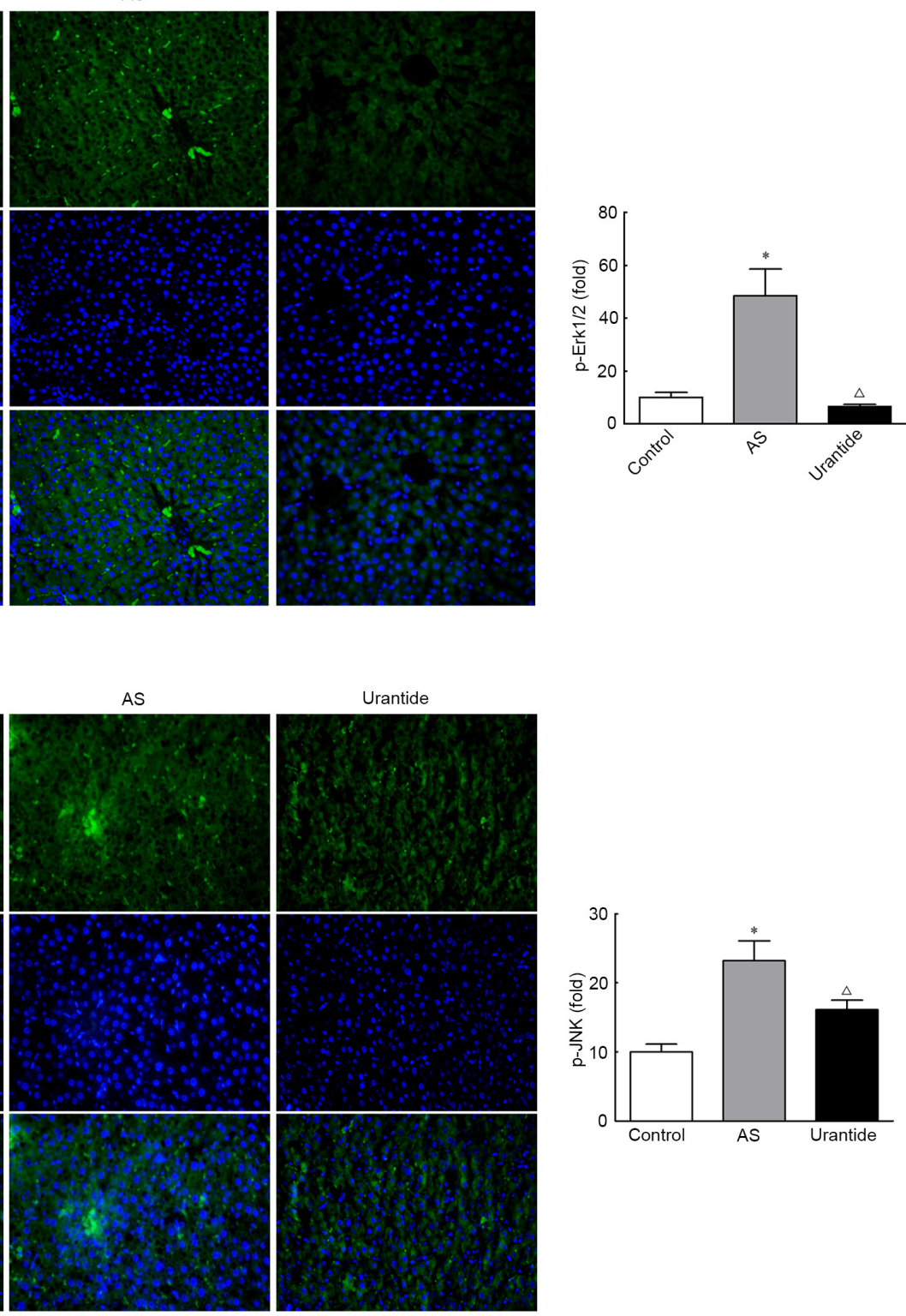

Figure 5. Images of immunofluorescence staining for p-Erk1/2 and p-JNK in the liver tissues of rats in different groups. (A) Expression levels of p-Erk1/2-positive particles in the rat liver were determined using immunofluorescence staining. (B) Expression levels of p-JNK-positive particles in the rat liver were determined using immunofluorescence staining. The proteins were stained with FITC (green). The nuclei were stained with DAPI (blue). Scale bar, $20 \mu \mathrm{m}$. The data are presented as the mean $\pm \mathrm{SEM}, \mathrm{n}=3$ animals per group. ${ }^{*} \mathrm{P}<0.05$ vs. control group; ${ }^{\mathrm{A}} \mathrm{P}<0.05$ vs. AS group. AS, atherosclerosis; $\mathrm{p}-$, phosphorylated.

suggested that the molecular mechanism via which hepatic steatosis occurs in rats with AS is via UII/GPR14-mediated increases in Erk1/2 and JNK phosphorylation in the liver, which activates the Erk/JNK signaling pathway and promotes the occurrence of hepatic steatosis in rats with AS.

Urantide is the strongest known UII receptor antagonist, and the antagonist effect is 50-100 times higher compared with other compounds such as endothelin-1 $(32,33)$. The present study examined the literature but found few reports describing the association of urantide with AS. At present, to the best of our knowledge, only the authors' research team has provided a small amount of evidence indicating that urantide blocks the effects of UII on promoting the occurrence and development of AS $(10,11)$. Concurrently, as shown in our previous studies using an AS rat model, urantide exerted protective effects on myocardial collagen metabolism disorder (34) and kidney injury (35), and the survival rate of rats with AS was also greatly improved by injecting with $30 \mu \mathrm{g} / \mathrm{kg}$ urantide. As to whether human patients are suitable for this dose, it is necessary to determine the best dose for patients by converting the equivalent dose between animals and humans. Nevertheless, the study of urantide is still in the basic research stage and has not yet been used in clinical trials, and its safety needs to be verified in future studies.

The detailed mechanism via which urantide affects AS remains unknown. The present study examined the effect of urantide on signaling molecules in the Erk1/2 and JNK pathways in the rat liver to further evaluate the mechanism via which urantide regulates Erk1/2 and JNK signaling in AS rats with hepatic steatosis. The expression levels of UII and GPR14 in the livers of the urantide group were significantly decreased, and levels of Erk1/2 and JNK phosphorylation were reduced. The immunofluorescence staining further revealed a marked 


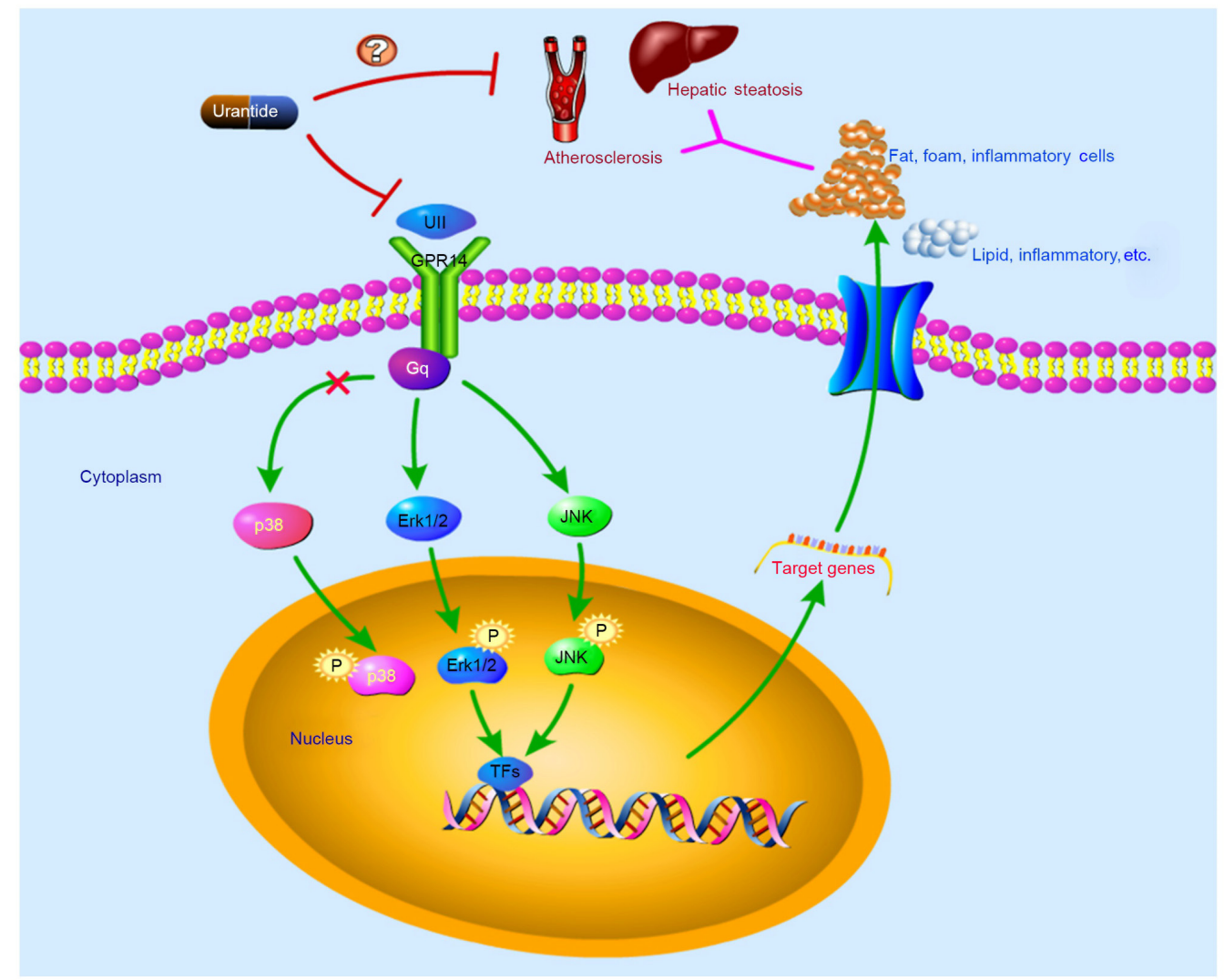

Figure 6. Diagram of the proposed mechanism via which urantide regulates the UII/GPR14/MAPK/Erk/JNK signaling pathway in the livers of rats with AS The UII antagonist urantide blocks UII binding to GPR14. AS, atherosclerosis; UII, urotensin II; GPR14, G protein-coupled-receptor 14; Gq, subtype of G protein; TFs, transcription factors; p, phosphorylated.

decrease in the number of p-Erk1/2- and p-JNK-positive cells in the liver after treatment with urantide. These findings confirmed the hypothesis that by inhibiting UII/GPR14 expression, urantide reduces the release of pathogenic factors after injury to liver function and the development of hepatic steatosis in rats with AS, thus ameliorating the AS-related pathological changes in rats. Collectively, it was suggested that urantide inhibited the phosphorylation of Erk1/2 and JNK by blocking UII binding to its receptor GPR14 (Fig. 6), thereby alleviating liver function damage and hepatic steatosis in rats.

In conclusion, the treatment of AS rats with urantide ameliorated hepatic steatosis and significantly improved lipid deposition and liver functions. The underlying molecular mechanism may be associated with the inhibition of the UII/UT system by urantide. The present study examined the relationship between the MAPK pathway and the UII/GPR14 system in hepatic steatosis in rats with AS. It was identified that urantide inhibited the activation of Erk1/2 and JNK, thereby alleviating hepatic steatosis and AS lesions. However, it was not determined whether the UII/GPR14 system directly regulates the MAPK pathway and how it regulates lipid metabolism. The main limitation of this study is the lack of validation of the downstream genes regulated by the MAPK pathway that affect lipid metabolism. Therefore, in further studies of urantide, the mechanisms via which urantide protects the liver to restrain AS development will be further clarified. The present study does provide novel perspectives and an experimental basis for the clinical use of urantide to treat AS.

\section{Acknowledgements}

Not applicable.

\section{Funding}

The study was supported by the Natural Science Foundation of Hebei Province of China (grant no. H2020406011), the Youth Science and Technology Research Project of Health and Family Planning Commission in Hebei Province (grant no. 20200183), Hebei Provincial Department of Education Key Project (grant no. ZD2019098), Chengde Medical University Natural Science Youth Fund (grant no. 201922) and Fund for Key Discipline Construction Projects in Hebei Province [grant no. Hebei (2013) 4].

\section{Availability of data and materials}

The datasets used and/or analyzed during the current study are available from the corresponding author upon reasonable request.

\section{Authors' contributions}

JZ and HPC conceived and designed the study. HPC, YXL and LDX performed the experiments. HPC and YXL analyzed the data. HPC and YXL wrote the paper. JZ, HPC and YXL confirm the authenticity of all the raw data. All authors read and approved the final manuscript. 


\section{Ethics approval and consent to participate}

All animal procedures were ethically approved (approval no. CDMULAC-20171218009) by the Experimental Animal Care and Use Committee of Chengde Medical University (Chengde, China) and were conducted in accordance with the National Institutes of Health Guide for the Care and Use of Laboratory Animals.

\section{Patient consent for publication}

Not applicable.

\section{Competing interests}

The authors declare that they have no competing interests.

\section{References}

1. Gaudio E, Nobili V, Franchitto A, Onori P and Carpino G: Nonalcoholic fatty liver disease and atherosclerosis. Intern Emerg Med 7 (Suppl 3): S297-S305, 2012

2. Guth S, Windler E, Leise U and Bamberger CM: Ultrasound Diagnosis of Hepatic Steatosis as a Surrogate for Atherosclerosis. Ultrasound Int Open 2: E27-E31, 2016.

3. Kapuria D, Takyar VK, Etzion O, Surana P, O'Keefe JH and Koh C: Association of Hepatic Steatosis With Subclinical Atherosclerosis: Systematic Review and Meta-Analysis. Hepatol Commun 2: 873-883, 2018

4. Ross B, McKendy K and Giaid A: Role of urotensin II in health and disease. Am J Physiol Regul Integr Comp Physiol 298: R1156-R1172, 2010.

5. Brancaccio D, Limatola A, Campiglia P, Gomez-Monterrey I, Novellino E, Grieco P and Carotenuto A: Urantide conformation and interaction with the urotensin-II receptor. Arch Pharm (Weinheim) 347: 185-192, 2014.

6. 6. Svistunov AA, Tarasov VV, Shakhmardanova SA, Sologova SS, Bagaturiya ET, Chubarev VN, Galenko-Yaroshevsky PA, Avila-Rodriguez MF, Barreto GE and Aliev G: Urotensin II: Molecular Mechanisms of Biological Activity. Curr Protein Pept Sci 19: 924-934, 2018.

7. Bigeard J and Hirt H: Nuclear Signaling of Plant MAPKs. Front Plant Sci 9: 469, 2018

8. Keshet Y and Seger R: The MAP kinase signaling cascades: A system of hundreds of components regulates a diverse array of physiological functions. Methods Mol Biol 661: 3-38, 2010.

9. Ziltener P, Mueller C, Haenig B, Scherz MW and Nayler O: Urotensin II mediates ERK1/2 phosphorylation and proliferation in GPR14-transfected cell lines. J Recept Signal Transduct Res 22: $155-168,2002$

10. Zhao J, Yu QX, Kong W, Gao HC, Sun B, Xie YQ and Ren LQ: The urotensin II receptor antagonist, urantide, protects against atherosclerosis in rats. Exp Ther Med 5: 1765-1769, 2013.

11. Zhao J, Xie LD, Song CJ, Mao XX, Yu HR, Yu QX, Ren LQ, Shi Y, Xie YQ, Li Y, et al: Urantide improves atherosclerosis by controlling C-reactive protein, monocyte chemotactic protein-1 and transforming growth factor- $\beta$ expression in rats. Exp Ther Med 7: 1647-1652, 2014

12. Gou SH, Liu BJ, Han XF, Wang L, Zhong C, Liang S, Liu H, Qiang Y, Zhang Y and Ni JM: Anti-atherosclerotic effect of Fermentum Rubrum and Gynostemma pentaphyllum mixture in high-fat emulsion- and vitamin D3-induced atherosclerotic rats. J Chin Med Assoc 81: 398-408, 2018.

13. Huang ZY, Yang PY, Almofti MR, Yu YL, Rui YC and Yang PY: Comparative analysis of the proteome of left ventricular heart of arteriosclerosis in rat. Life Sci 75: 3103-3115, 2004.

14. Li X, Li X, Luo R, Wang W, Wang T and Tang H: Detection of KIT genotype in pigs by TaqMan MGB real-time quantitative polymerase chain reaction. DNA Cell Biol 37: 457-464, 2018.

15. Livak KJ and Schmittgen TD: Analysis of relative gene expression data using real-time quantitative PCR and the 2(-Delta Delta C(T)) Method. Methods 25: 402-408, 2001.
16. Lu YW, Zhu YC, Zhang L, Li P, Yang J and Wen XD: Ilexgenin A enhances the effects of simvastatin on non-alcoholic fatty liver disease without changes in simvastatin pharmacokinetics. Chin J Nat Med 16: 436-445, 2018.

17. Targher G, Bertolini L, Padovani R, Rodella S, Zoppini G, Zenari L, Cigolini M, Falezza G and Arcaro G: Relations between carotid artery wall thickness and liver histology in subjects with nonalcoholic fatty liver disease. Diabetes Care 29: 1325-1330, 2006.

18. Di Minno MN, Di Minno A, Ambrosino P, Songia P, Tremoli E and Poggio P: Aortic valve sclerosis as a marker of atherosclerosis: Novel insights from hepatic steatosis. Int J Cardiol 217: 1-6, 2016.

19. Lee SB, Park GM, Lee JY, Lee BU, Park JH, Kim BG, Jung SW, Jeong ID, Bang SJ, Shin JW, et al: Association between non-alcoholic fatty liver disease and subclinical coronary atherosclerosis: An observational cohort study. J Hepatol 68: 1018-1024, 2018.

20. Pearson D, Shively JE, Clark BR, Geschwind II, Barkley M, Nishioka RS and Bern HA: Urotensin II: A somatostatin-like peptide in the caudal neurosecretory system of fishes. Proc Natl Acad Sci USA 77: 5021-5024, 1980.

21. Gabunia K, Jain S, England RN and Autieri MV: Anti-inflammatory cytokine interleukin-19 inhibits smooth muscle cell migration and activation of cytoskeletal regulators of VSMC motility. Am J Physiol Cell Physiol 300: C896-C906, 2011.

22. Segain JP, Rolli-Derkinderen M, Gervois N, Raingeard de la Blétière D, Loirand $G$ and Pacaud P: Urotensin II is a new chemotactic factor for UT receptor-expressing monocytes. J Immunol 179: 901-909, 2007.

23. Watanabe T, Suguro T, Kanome T, Sakamoto Y, Kodate S, Hagiwara T, Hongo S, Hirano T, Adachi M and Miyazaki A: Human urotensin II accelerates foam cell formation in human monocyte-derived macrophages. Hypertension 46: 738-744, 2005.

24. Sun H, Zhang L and Shen D: Urantide protects CCl4-induced liver injury via inhibiting GPR14 signal in mice. Biotechnol Biotechnol Equip 31: 156-161, 2017.

25. Liang DY, Liu LM, Ye CG, Zhao L, Yu FP, Gao DY, Wang YY, Yang ZW and Wang YY: Inhibition of UII/UTR system relieves acute inflammation of liver through preventing activation of NF- $x$ B pathway in ALF mice. PLoS One 8: e64895, 2013.

26. Liu LM, Zhao L, Liang DY, Yu FP, Ye CG, Tu WJ and Zhu T: Effects of urotensin-II on cytokines in early acute liver failure in mice. World J Gastroenterol 21: 3239-3244, 2015.

27. Watanabe T, Kanome T, Miyazaki A and Katagiri T: Human urotensin II as a link between hypertension and coronary artery disease. Hypertens Res 29: 375-387, 2006.

28. Cseh B, Doma E and Baccarini M: 'RAF' neighborhood: Protein-protein interaction in the Raf/Mek/Erk pathway. FEBS Lett 588: 2398-2406, 2014.

29. Hwang HJ, Jung TW, Hong HC, Seo JA, Kim SG, Kim NH, Choi KM, Choi DS, Baik SH and Yoo HJ: LECT2 induces atherosclerotic inflammatory reaction via CD209 receptor-mediated JNK phosphorylation in human endothelial cells. Metabolism 64: 1175-1182, 2015.

30. Reustle A and Torzewski M: Role of $\mathrm{p} 38$ MAPK in atherosclerosis and aortic valve sclerosis. Int J Mol Sci 19: 3761, 2018.

31. Kardakaris R, Gareus R, Xanthoulea S and Pasparakis M: Endothelial and macrophage-specific deficiency of P38 $\alpha$ MAPK does not affect the pathogenesis of atherosclerosis in ApoE-/- mice. PLoS One 6: e21055, 2011.

32. Leprince J, Chatenet D, Dubessy C, Fournier A, Pfeiffer B, Scalbert E, Renard P, Pacaud P, Oulyadi H, Ségalas-Milazzo I, et al: Structure-activity relationships of urotensin II and URP Peptides 29: 658-673, 2008.

33. Guidolin D, Albertin G and Ribatti D: Urotensin-II as an angiogenic factor. Peptides 31: 1219-1224, 2010.

34. Wang T, Sun X, Cui H, Liu K and Zhao J: The peptide compound urantide regulates collagen metabolism in atherosclerotic rat hearts and inhibits the JAK2/STAT3 pathway. Mol Med Rep 21: 1097-1106, 2020

35. Wang T, Xie YQ, Miao GX, Cui HP, Liu K, Li Y, Li Y and Zhao J: Urotensin receptor antagonist urantide improves atherosclerosis-related kidney injury by inhibiting JAK2/STAT3 signaling pathway in rats. Life Sci 247: 117421, 2020.

This work is licensed under a Creative Commons Attribution-NonCommercial-NoDerivatives 4.0 International (CC BY-NC-ND 4.0) License. 